Article

\title{
Take Care of Your Scar(f), Lilya! De-stigmatizing the Image of the Post-Soviet Other in Nordic Cinema*
}


ABSTRACT

The article discusses the cinematic representations of the post-Soviet individual in two internationally acclaimed Nordic films, namely, Aki Kaurismäki's Take Care of Your Scarf, Tatiana (Pidä huivista kiinni, Tatjana, Finland/Germany, 1994) and Lukas Moodysson's Lilya 4-Ever (Lilja 4-ever, Sweden/Denmark, 2002). The guiding premise is that the films represent cross-cultural inquiries on identity and otherness that reflect and challenge the (male) gaze of the West European North upon the (female) post-Soviet East soon after the collapse of the communist regimes in Eastern Europe.

The following comparative reading stems from an observation of the cinematic representations of identity and otherness, national and foreign, in two Nordic films that met with the approval of critics as well as audiences throughout Europe. The films are Take Care of Your Scarf, Tatiana (Pidä huivista kiinni, Tatjana, Finland/Germany, 1994) by Aki Kaurismäki and Lilya 4-Ever (Lilja 4-ever, Sweden/Denmark, 2002) by Lukas Moodysson. The films are quite different in aesthetic, thematic, and generic terms. Kaurismäki's black-and-white pastiche-styled road movie has hardly anything in common with Moodysson's realistically coloured, ruthless drama. Kaurismäki's idiosyncratic cinematic language is miles away from the naturalistic auteurship of Moodysson. However, they both settle on an undemanding linear narrative that best renders the virtue of their marginal characters and they both voice strong social criticism. Moreover, the films present highly intriguing images of the Eastern European individual, and, by reference, of Eastern Europe before and after the fall of the Berlin Wall - images that are produced from the external perspective of two acclaimed directors of the Nordic cinema.

Accordingly, the theoretical background of this reading is informed by the discussion of the concepts of identity and otherness that has taken place in contem- porary continental philosophy, especially in gender and postcolonial studies. A common view expressed in this discussion has been that master dichotomies are operating in the cognition and representation of subjects and groups in Western civilization, such as male and female, master and slave, national and foreign, we and they, western and eastern, etc. These oppositions derive from a fundamental philosophical distinction between the subject and the object, the Self and the Other, which is intrinsically connected to the constitution of power relations and the asymmetric distribution of power among individuals. Hegel's parable of the master and the slave, presented in his Phenomenology of Spirit (Phänomenologie des Geistes, 1807) has provided special incentive for speculations on the intersubjective mechanics of power. According to this parable, the self-consciousness of a subject arises from an encounter and "battle to death" with another human being. Drawing on Hegel, Simone de Beauvoir asserted that "the subject can be posed only in being opposed - he sets himself up as the essential, as opposed to the other, the inessential, the object" ([1949] 1989: xxiii; my emphasis).

The current article does not engage in an ontological consideration of the problem, but rather focuses on its intercultural aspects by examining certain tropes in 
the cinematic representations of Eastern European individual in two Nordic films. Specifically, in this case, the Other is considered to be an image based on a more or less typified individual representation, a film character or characters who are usually intentionally constructed to seem different from or even oppose the Self, and thus to define them by opposition. The social making of the Other, or "othering", is achieved by presuming a hierarchical difference based on national, gender, or class identity, among others. In the Nordic films under discussion, the Other is represented by the image of a young woman from the Eastern Bloc, that is, through an image clearly implying gender and geopolitical distinctions.

These two instances of the Other the female and the Easterner - have found ample theoretical consideration, for example, in Simone de Beauvoir's The Second Sex (1949) and in Edward Said's Orientalism (1978). Interestingly, Beauvoir introduces us to the problem of female otherness with the stereotypical example of Russian women, who, according to the proponents for the eternal feminine, are "still women" in comparison to their emancipated Western counterparts (Beauvoir [1949] 1989: xix; emphasis in the original). In this seminal feminist text, Beauvoir further dismantles the popular idea about "women", femininity and the female sex as "the sex" and refutes the reduction and objectification of the social position of women that is used to define and differentiate women from men: "He is the Subject, he is the Absolute - she is the Other" (Beauvoir [1949] 1989: xxii; my emphasis). In Beauvoir's view, men had "othered" women by mystifying and romanticising them, and by inventing the myth of women being eternal, but feeble, capricious, and devoid of reason. Edward Said's postcolonial critique, on the other hand, attacks the subtle but persistent westEurocentric prejudice about the inferiority of the Eastern (Muslim) people and their cultures (Said [1978] 2003: 3). According to him, Western culture has created a powerful discourse, Orientalism, which represents the East (the Middle East or the Orient, but also by analogy Asia), as "passive, seminal, feminine, even silent and supine" (ibid.: 138; my emphasis); that is, as a feminised Other, irrational, weak, often despotic, and bizarre in its cultural practices; a negative image that is contrasted to the rational, strong, and masculine West. Thus, a woman and an Oriental Easterner become cultural signs constructed in opposition to the white Western male as the essential and the universal. In Beauvoir's and Said's view, men have "othered" women and the educated elites in the West have created a view of the Orient by inventing a hierarchy that legitimises their (male, Western) right to dominance.

Several historians and humanities scholars have implemented Said's perspective in regard to Eastern Europe as a sub-cultural region within Europe - for example, Larry Wolff in his Inventing Eastern Europe: The Map of Civilization on the Mind of Enlightenment (1994), Milica BakićHayden in her article, "Nesting Orientalisms: The Case of Former Yugoslavia" (1995) or Maria Todorova in her study, Imagining the Balkans (1997). Their research has shown that similar discursive practices based on binary oppositions, civilising rhetoric, semicolonialist policies, and "othering" have shaped the Western imagination about the eastern parts of the continent as the backward periphery of European civilization: "It was Western Europe that invented Eastern Europe as its complementary other half in the eighteenth century, during the age of Enlightenment. It was also the Enlightenment, with its intellectual centers in Western Europe, that cultivated and appropriated to itself the new notion of "civilization", an eighteenth-century neologism, and civilization discovered its complement, within the same continent, in the shadowed lands of backwardness, even barbarism" (Wolff 1994: 4; my emphasis). However, the outlining of Eastern Europe as a different and opposed cultural zone occurred during the Cold War, when it was seen as an adversary political entity. Winston Churchill coined the powerful metaphor of the Iron Curtain that had cut through the middle of the continent "from Stettin in the Baltic to Trieste in the 
Adriatic" and cast a deep shadow over the left-side other Europe, so that the eastern parts were once again associated with the realm of darkness (Wolff 1994). After the fall of the Berlin Wall in 1989, Europeans from both sides seemed to celebrate the abolishment of the division, obviously, with higher enthusiasm and greater expectations in the former "dark" parts. However, the transition to a market economy and western-style democracy proved to shed little light on these regions and came to be considered defective by a large part of Eastern Europeans. However, at the same time, large numbers of Western Europeans developed anxious and hostile feelings towards the immigrants coming from the poorer Eastern European countries. The sad truth, according to Wolff, has been that, although the Iron Curtain is gone, its shadow persists in the mind maps of Europeans (1994: 3).

Therefore, it is important to further examine in what kind of shapes and nuances the shadows characterising Eastern Europe reappear on the cultural maps of Europeans, the Nordic cinema being one of the stages and customary agents in the negotiation of images between West and East.

In the selected Nordic films, the Other is the foreign neighbour from the post-Soviet East. During the Cold War and behind the Iron Curtain, this figure used to simultaneously frighten and attract. For example, in probably the most successful Finnish film of all times, The Unknown Soldier (Tuntematon sotilas, 1955, directed by Edvin Laine), which became a canonical representation of the Continuation War between Finland and the Soviet Union that lasted from 1941 to 1944, the Red Army is portrayed as a dangerous and anonymous aggressor whose soldiers are always shown from a distance, attacking in swarms the individualised squads of Finns. The Unknown Soldier is based on the likewise classic novel by Väinö Linna (1954) that was adapted to the screen again in 1985 (directed by Rauni Mollberg). Laine's film of 1955 became a national cult object, for it has been regularly broadcast on TV on Finnish Independence Day. It is predominantly an anti-war informed and realistic portrayal of a group of Finnish recruits representing different social strata of wartime Finnish society. Although it deals with war against the eastern neighbour, the film hardly depicts any individual Soviet men. There is only one short episode with a Soviet officer who is taken prisoner. During the few minutes he comes into focus, he is shown proudly mute, remaining an exemplary background actor, a part that is ultimately played by the entire Red Army in this film. There are also a couple of shots of the adversary soldiers' lifeless bodies, which suggest that the frightening enemy could be looked at only if captive or dead.

In the film's generally coldly respectful attitude to the "Russkies", a positive contrast is struck by a scene of aesthetic and emotional fascination that focuses on a Russian-Karelian girl named Veera. It is one of the rare moments showing the romantic side of the Finnish men who are typically engaging in witty conversation at their posts or fighting and running back and forth on the frontlines. This scene takes place at a modest party held in the girl's peasant house. Being courted in vain by everybody, the beauty from Petrozavodsk is asked to dance the Kalinka in the middle of the room. As she spins faster and faster with a tulle scarf in her hand, close-ups of the fascinated gazes of the Finnish fighters reveal their sentimental delight. However, the foreign girl remains an exotic object of desire only to be contemplated. The Unknown Soldier - as a classical Finnish novel, two popular screen adaptations, and even an opera - shows how the figure of the Eastern European Other is modelled in the imagination of the Western North, and particularly in the Finnish cultural context of post-World War II. Therefore, The Unknown Soldier offers two representational options for the Soviet Other, embellished with precautions: if he is disguised as a dangerous man with a rifle the camera approaches him only when he is disarmed or dead; and if he appears objectified as a beautiful woman with a scarf admiration is permitted but only at a safe distance from her perilous charm. 
After the collapse of the Soviet Union, the Eastern Other suddenly appeared as a weak rival, a loser, and presumably easy prey - one could say - a "femme non-fatale". At the very least, this is how s/he appears in Kaurismäki's and Moodysson's films: in the early 1990s (in Tatiana), as a sort of ironic retrospection of the Cold War era and in the early 2000s (in Lilya) as an earnest account of the abnormality of the first post-Soviet decade.

\section{Kaurismäki's Take Care of Your Scarf,} Tatiana is said to be "the summary and even the quintessence of his work" (Kaurismäki, Hukkanen 1997: 173). It reveals the Finnish national character, as imagined by Kaurismäki, through an encounter of two provincial Finnish men with two, just as provincial, Soviet girls. Styled in the free spirit of the 1960s, the film depicts the Finns on a drive through the Finnish provinces where they are accidentally "hitchhiked" by two timid socialist girls who politely ask them for a ride to the ferry. During the journey each character is manifested through his or her national, gender and individual idiosyncrasies, which are revealed through an ironical play with the corresponding collective prejudices. The journey ends in Tallinn with a love relationship between Reino (Matti Pelonpää) and the Estonian Tatiana (Kati Outinen), Klaudia's (Kirsi Tykkyläinen) departure to Alma Ata, and Valto's (Mato Valtonen) return to Finland. In fact, Kaurismäki's film is a sardonic postmodern account of the paradigm of oppositions between western and eastern, self and other, male and female, which deliberately stages the story of their civilizational encounter in the natural settings of the Finnish countryside and further highlights the provincial, ex-centric, and socially marginal characteristics of all four dramatic personae.

Lukas Moodysson's Lilya 4-Ever, on the contrary, makes a serious critical comment on the current state of neglect, stigma, and abuse of the Other - be it a female, child, or Easterner - by the local post-Soviet as well as Western societies. It is inspired by the true story of sixteen-year-old Lithua- nian Danguolè Rasalaitè, who took her life by jumping off a highway bridge in Malmö, Sweden in January 2000, after being forced into prostitution for months. The case stirred considerable public debate in Sweden about human trafficking from the former Eastern Bloc and indirectly contributed to the implementation of changes in Swedish prostitution legislation. The film, which was shot two years later, performed well in the Nordic countries and at international festivals, and has been generally very positively received by critics and audiences, including in Russia and the former Eastern Bloc countries. Moodysson shot his film predominantly in Russian with Russian actors, and used the outskirts of Paldiski in Estonia and Malmö in Sweden for the exteriors. This provided a special authentic air to the depiction of Lilya's (Oksana Akinshina) personality, and the quite Eastern European tragedy, and made the external Nordic gaze almost invisible. The camera, which is prone to close-ups, follows her downfall almost intimately from the first scene when Lilya is abandoned by her mother who departs for America with her new boyfriend leaving her teenage daughter behind without any support. Lilya suffers subsequent betrayals at the hands of her relatives, neighbours, and friends, so that the girl starts to occasionally prostitute herself in order to buy food. Finally her new boyfriend, who spots her amateur seduction games in a disco bar, promises to organise a better life for her in Sweden. He arranges a false passport for her and delivers the unsuspecting Lilya directly into the hands of the Swedish sex trade mafia, which is organised by Eastern Europeans. In Sweden, Lilya lives locked-up alone in a flat or abused by her pimp and his clients. Finally, she escapes her prison by chance, and after running in despair through the concrete desert of the urban outskirts, she throws herself from a highway bridge and ends her life.

In truth, both films articulate and criticise the popular perception of the feminised and semi-colonised Eastern Other that was made to obey the global rules of capital, to be driven by its whims (like Tatiana 
and Klaudia in the Finnish men's car), and even perform according to its pleasures (like Lilya in her pimp's and his clients' bedrooms). Moreover, in a postmodern gesture of contesting inter-cultural stereotypes, both films establish and then undermine a speculative representation formed of clichés and stigmas that epitomises the figure of the Easterner as an object of desire and a body in subjection. I find Tatiana's scarf and Lilya's scar to be almost homonymic symbols of this representational model. Significantly, Tatiana's scarf is a puzzle posed by the very title of the film. The scar, on the other hand, is a metonymy of Lilya's beaten face, which the viewer witnesses in the opening and closing shots of the film with a strong disquiet. Both signs appear to acknowledge male-female and masterslave dialectics that direct the imagery of the Western Self in relation to the Eastern Other. However, the artistic ambitions of the two films challenge these conventional dialectics and their stigmatising bases. Therefore, I will organise my interpretation as an exercise in thesis, antithesis, and synthesis in order to explore the films' subversive compositions. In short, I will consider the scarf as related to a sentimental and affirmative representation of the Other, whereas the scar will denote a dominating and even abusive attitude towards Her.

Concerning the Western gaze, or the point of view from which the Other is judged, I will make use of another antithetic pair that critics noted in Kaurismäki's films - the paradox between "excessiveness" and "authenticity" (Nestingen 2005). This also proved to be useful even in regard to Moodysson's very distinct style. In particular, it means that by amassing clichés about the Other and the Self one emphasises their inherent reductiveness and thus questions their "truths". Kaurismäki's buffo-aesthetics use an almost Brechtian approach to achieve this effect. He uses slapstick exaggeration that evokes the spectator's ironical distancing. Kaurismäki's ethical horizon is also idealised to the point of sentimentality, which ultimately turns Tatiana into a melodramatic comedy. In Moodysson's drama, the excessiveness resides in the overproduction of the scenes of cruel realism and existential deadlock. Their accumulation gets so unbearable that the viewer - who identifies with the protagonist Lilya - is made to comprehend and transcend her suffering through her victimisation. As a result, Moodysson's work can be viewed as melodramatic tragedy.

The combination of these characteristics in the following analytic structure enables a study of the cinematic image of the Easterner as a site of perceived (imagined) "otherness" as opposed to the Western Self, which acts as the almost invisible perceiver (imaginer) in the films:

Thesis (scarf):
positive Other + excessiveness
Antithesis (scar):
negative Other + authenticity
Synthesis scar(f):
positive Other + authenticity

The thesis conceives an overall positive perception of the Other. It presents the Easterner as a long-lasting object of desire, in the sense of being a historical site of vital material resources from which geopolitical aspirations and collective ressentiments arise. The Easterner's valuable materiality is presented in the films through beautiful and young female bodies that are, on the one hand, invested with the ideals of purity, i.e. with images of the uncivilised and the savage blending together into a virginal image. However, this ideal resides in disavowal, frustration, and an excessive attempt on the part of the Western Self to distance itself from it, to escape into the cultural distinction of the civilised and the decadent, which is, by all means, achieved and even hyperbolised in the films.

The antithesis is presented in the films through a series of subtle negations of the idealised image of the Other in the leading roles (both Tatiana and Lilya) by contextualising them in relation to similar accompanying "others" (other Russian women, for 
instance, Tatiana's and Lilya's more practical girlfriends) and in relation to their post-Soviet cultural macrocosm, a place of misery, violence, and desperation in Moodysson's depiction. This negative scrutiny involves a strong drive to reach an authentic Other, to reveal the matter of her body in its "true" submissiveness and "ultimate" disgrace, which directs the perception to yet another cliché and counter-ideal, to that of the prostitute.

The synthesis finally comes to represent the artistic endeavour of both filmmakers to raise the contradictions imposed by the previous stages to another level, which is probably more wishful than feasible, but truly empathic. Synthesis is by definition a negation of the negation (of the antithesis) and a re-evaluation of the suppositions (of the thesis). Therefore, it imagines an optimal recognition of the Other and an ethical concern of solidarity with Her, while remaining idealistic. The synthesis is represented in the films' endings by the sequences of dreamlike phantasms. They consist of another type of imaginary, a declaratively positive and humane one, which both cinematic works use to overcome the popular prejudices and their clichéd images, and which take the form of the films' messages.

\section{THE SCARF. THESIS: POSITIVE OTHER + EXCESSIVENESS}

Both films set up a positive representational model of the Other that I chose to symbolise here with a scarf. Generally speaking, a scarf covering the head of a woman characterises her as having a series of qualities such as humbleness, chastity, innocence, traditionalism, backwardness, and outmoded style. All this is applicable to Veera, the RussianKarelian female character in the early Finnish classic The Unknown Soldier, who dances with a small scarf. Her image could be seen as a prototype of the modern representations of Tatiana and Lilya.

Tatiana keeps wearing her tulle headscarf during the journey and takes it off only on occasions related to pleasure, i.e. in the evening, at a restaurant, while dancing, or at night while alone with Reino in the hotel room. The only moment when the scarf is left to fall, and is carried off by the sea wind, is the most romantic moment in the film. The removal of the scarf changes nothing in Tatiana's modest attitude. She is always polite, still, and passive, and only momentarily gets animated while taking pictures of banal objects with her old-fashioned camera. She is reticent and if she says anything it is a pure cliché of an official discourse that can be defined as phony Soviet politeness. The fact that she does not appear to be phony is the result of Kaurismäki's stylish use of clichés throughout the film, something that I will return to later.

By contrast, the much younger Lilya does not wear a scarf. However, the positive characteristic of purity is also marked by a symbolical object with similar connotations (humbleness, chastity, traditionalism). This is the icon that Lilya always keeps with her and which depicts a wandering child accompanied by an angel. Lilya is herself portrayed as a naïve, adolescent spirit, and angelic beauty. (Figure 1)

In addition, her name implies purity, since the lily is a sign of the Virgin Mary. Moreover, the film's title Lilya 4-Ever, which is an inscription the teenage Lilya cuts into a bench, identifies her as an immaculate and eternal virgin and conceives sex slavery as a form of martyrdom. Therefore, Moodysson has a venerable attitude toward the main character, as can been seen from the title, but it does not apply to the Eastern Other as such.

Therefore, the films' positive portrayal of the main female characters is somewhat exaggerated. Tatiana and Lilya are invested with the ideal of purity and perceived as radiant objects of desire. This is dangerous for the integrity of the perceiving male identity that urgently needs an interim shield, a firmly held veil on such a sublime object. That is why "Take Care of Your Scarf, Tatiana!" is less of a joke warning Eastern females than an inner imperative, voiced by a critical instance within the Western, Finnish Self. It lets a cultural taboo against desiring an Easterner slip, which automatically 


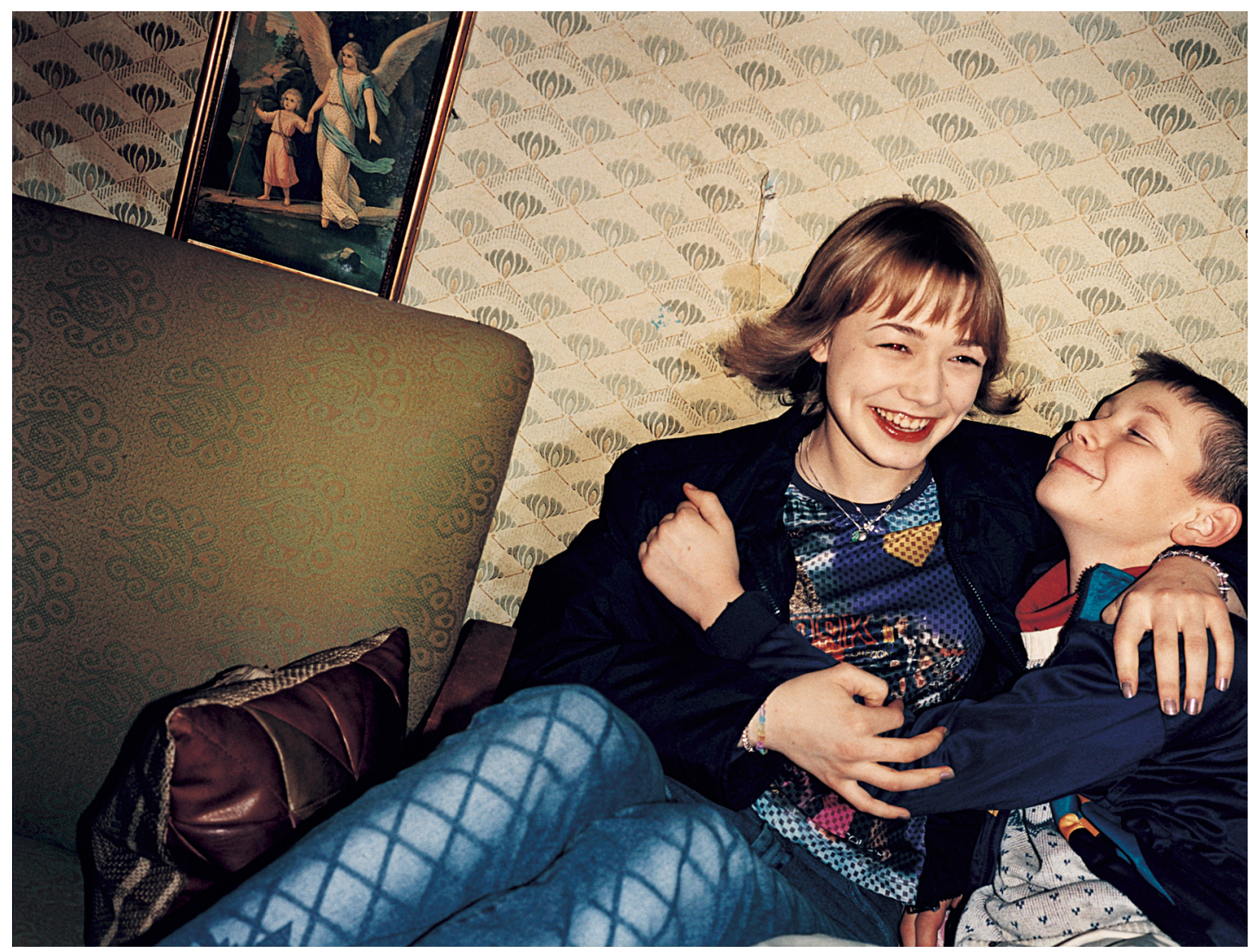

FIGURE 1. CMemfis Film/Per-Anders Jörgensen. 
activates a surplus of differential clichés about oneself. That is why Kaurismäki's Finnish male protagonists indulge in a comedic excess of ignorance, shyness, and stereotypical Finnishness (excessively drinking coffee and vodka, being silent, introvert, and businesslike), whereas Lilya's Swedish clients, conforming to the serious tone of the film, are overly naturalistically depicted as perverted, degenerate, and disgusting.

Then again, in Kaurismäki's film, there are barely any hard-line perspectives at all. He playfully elaborates on the positive or the negative, which are already understood to be clichés. The same applies to Tatiana's scarf and her "saintliness". Significantly, the film opens with extra-diegetic and non-narrative images of speeding motorcycles ridden by men with women wearing tulle headscarves sitting behind them. This is a reference to Carl Theodor Dreyer's short sarcastic film They Caught the Ferry (De nåede færgen, Denmark, 1948), which tracks the precipitous ride towards death of a motorcyclist and his headscarf-wearing female companion, revealing Kaurismäki's fascination with the work of the Danish classic and with filming motor speed and danger. This is also a sentimental homage to French and American cinema and fashion of the 1960s, and it is later ironically paraphrased by the images of Tatiana and her friend, Klaudia, sitting in the back seat of a 1968 Volga limousine driven by oddly modern Finnish guys. One could even claim that Tatiana is a peculiar Finnish compilation of nouvelle vague aesthetics combined with Easy Rider's (USA, 1969, Dennis Hopper) ethics, or vice versa. However, if this is true, what roles do the Estonian girl and her Russian companion play in the film's romantic and free-spirited narrative? (Figure 2)

Obviously, their pronounced female and Soviet otherness plays the functional role of being a counter-image to Western Self-identity, and to post-war (male) Finnishness that is the true object of Kaurismäki's film and irony.

On the one hand, the typical Russian name of Tatiana, or Svetlana as a draft title suggests (Pidä huivista kiinni Svetlana, nyt mennään; Elonet Kansallisfilmografia 2013), seems to operate almost as a collective noun, applicable to Russian women in general. On the other hand, Tatiana as a stranger coming from the left-side Other Europe personifies the "ideal" that, in Kaurismäki's filmic universe is, by definition, located outside or beyond the Finnish and Western capitalist reality. Many of Kaurismäki's characters (of the proletarian sort) try to escape the gloomy urban reality of Helsinki, or of Finland altogether (for instance, in Calamari Union, Finland, 1985; Ariel, Finland, 1988; Leningrad Cowboys Go America, Finland/Sweden, 1989). This ideal is always located on the Other's shores (Le Havre, Finland/France/Germany, 2011). It is connected to an "otherness" that is not only different from a national, ideological, or gender aspect, but to an ultimately humane "otherness" as the true virtue or ideal that Kaurismäki traces in individuals who are conventionally seen as marginal, worthless, notorious, and eventually despised. This applies to all of Kaurismäki's protagonists. Thus, in the film's romantic story, the Soviet girls signify the most socially abject and disreputable partners that conventional Finnish mentality could imagine for a love affair. In Kaurismäki's idiolect, this choice of "otherness" is a subversive tactic against the conforming and confining practices of the collective identity he belongs to. Therefore, Take Care of Your Scarf, Tatiana seems to explore and mildly mock the national Finnish identity for assuming a distinguished (male and Western) shape that hardens as a result of its encounter with its Eastern, female, and Soviet Other.

However, this is not the only aim of the film; Kaurismäki is a master at displaying the paradoxical interplay of difference and sameness. Interestingly, his film depicts the girls, and especially Tatiana, in a rather unappealing and unattractive manner. In the comic couple she forms with the selfassertive and somewhat plump Russian Klaudia, the thin Estonian Tatiana plays the dull, the inert, and the naïve. Her scarf, rigid behaviour, and clichéd way of speaking 


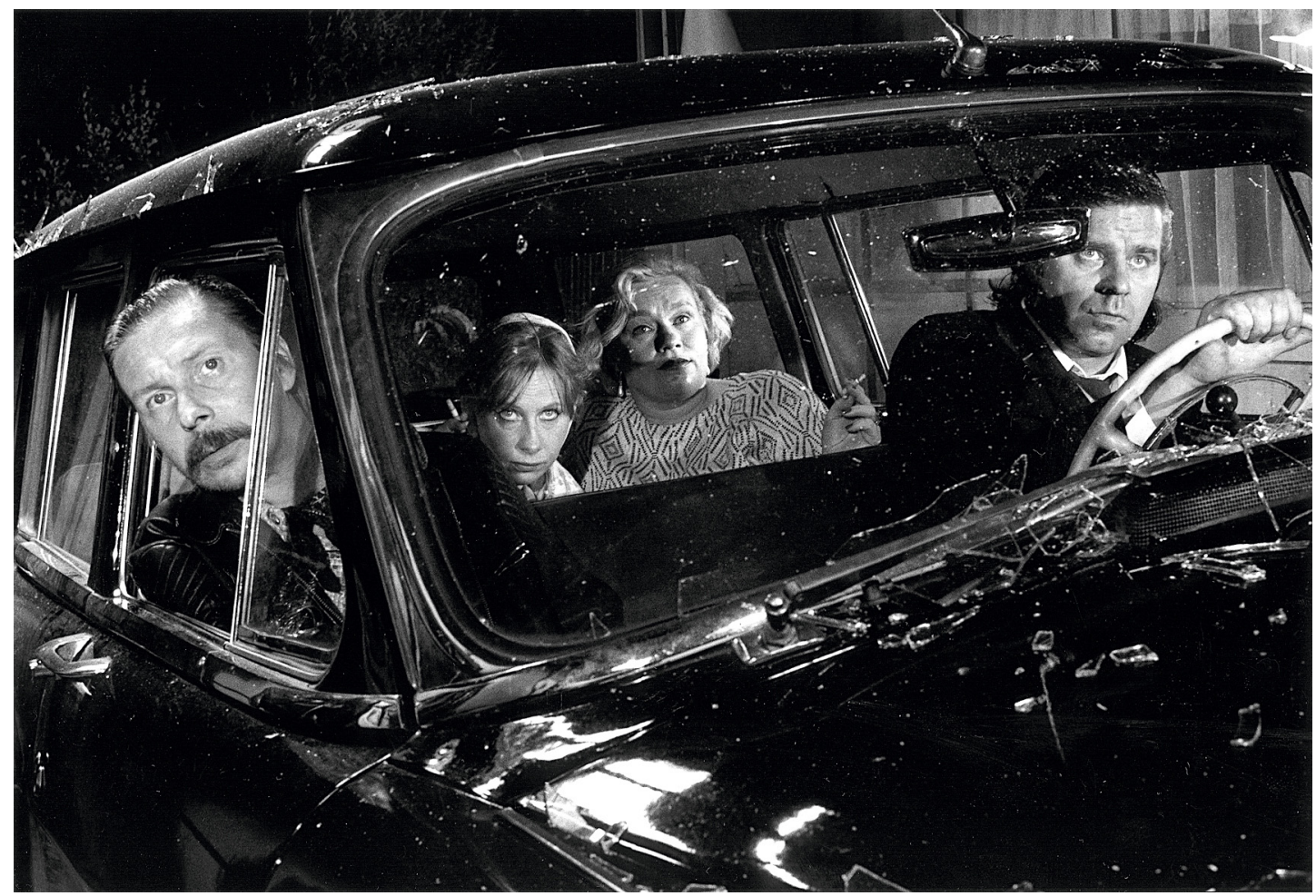

FIGURE 2. CSputnik OY.



FIGURE 3. CSputnik OY. 
make her excessively unromantic and unsexy, yet she conquers the heart of a tough Finnish man, like the rocker Reino. The narrative constantly evokes Reino's provinciality, his diffidence, sparing and banal speech as substantial parts of his behaviour and, therefore, reflects and recognises these features as characteristics of his identity, of his Finnishness. Gradually, in the course of his infatuation with Tatiana, his male façade peels off together with his hardboiled Finnishness. (Figure 3)

Scholars have spoken of Tatiana as "distilling an expression of post-war Finnish culture", and have argued that "of all Kaurismäki's films, Tatiana might be seen as the most fully developed version of the national auteur's picture of the national past" (Nestingen 2005: 297). Indeed, the film seems to be a persiflage of the national character as it has been appropriated by Kaurismäki's own generation, which was born in the late 1950s and raised in the 1960s and 1970s - formative years for the present Finnish identity. On the one hand, the Finnishness is depicted in its virile "thirst for Americana"", for enjoyment, movement, Western lifestyles, and modernity and, on the other, in an eager escape from the backwardness of the reindeer and puritan mentality of their parents. This is what underlies Reino's drunken jabber in the car scene at the beginning when he talks about boring Lapland, going down south, and being manly like a heavy drinking rocker. That is the impetus that drives Valto, thirsty for American coffee, from his maternal nest into a long drive through the country in the mood of the beat generation. And last but not least, that is the role of the rock 'n' roll music that dominates the soundtrack, even invading the barn dances and replacing the traditional iskelmä .

1 See Nestingen (2005: 285) citing Jonathan Romney: "Despite taking place in a fantasy pastiche dream of Kerouac gone Nordic - Tatiana is revealing about Finnish culture, about the thirst for Americana on the one hand and the fascination with the neighboring former USSR on the other" (Romney 2003: 45).

2 Iskelmä is the Finnish term for the schlager music style known for its sentimental lyrics, catchy melody, and light tunes that often turn the songs into hits and which became popular in Europe especially after World War II.
Furthermore, the film's score presents an essential commentary on the main antagonisms (male and female, western and eastern) that define the Finnish national character. There is an illustrative scene of how those involved in the modern rocker lifestyle despise the old-fashioned popular music culture and how this acts as a westernised masculine shield against the sentimentalising female East. The protagonists are sitting in a provincial restaurant where the performance of a local duo called Vepa (accordion) and Pepo (vocals) is announced. As the name of their Finnish song Anyushka suggests, its subject is a declaration of love for a Russian girl. After the boys do not invite them to dance, Tatiana and Klaudia dance together and amuse themselves alone. This prompts Reino to remark, "Stupid chicks." The musical genre is part of the character's worldview and lifestyle. In Kaurismäki's film these two genres almost become opposite ideological stances that - according to another popular cliché - paradoxically attract each other. As a rule, the music in Kaurismäki's films replaces many of the characters' lines and operates as the narrator's stance. The melos in Kaurismäki's favourite genre of melodrama often prevails over the drama, for instance, in his Leningrad Cowboys' musicals (Leningrad Cowboys Go America; Leningrad Cowboys Meet Moses, Finland/ Germany/France, 1994) that first made the Finnish director popular among young audiences throughout Europe. The music in Kaurismäki's cinema is seldom an extradiegetic element; it often springs from the settings and plays an active narrative role. For instance, in the minimalist verbal score for Tatiana, the cool rock ' $n$ ' roll sequences amass one after another in an almost nonstop and lengthy monologue, with the main topics being "love" and "girls", as if compensating for the lack of eloquence on the part of the male Finnish characters. The English rock 'n' roll songs definitely assume the dominant position in the film's soundtrack compared to the rather incidental popular hits in Finnish, sung by local old songsters. Actually, the sentimental iskelmä melodies 
appear almost as the odd, inappropriate interruptions of "silly girls" and, certainly, as examples of backward tastes, but ironically, they too recount "love" and "romance". The music in Tatiana literally verbalises the otherwise unspoken "male - female" and "our modern identity - their backward otherness" dialectic melodrama.

All in all, the cherished (masculine) westernisation of the Finnish national identity is presented in Tatiana through a permanent decline into (feminine) easternisation. The drive through the Finnish provinces may look like Kerouac's trip through the USA, but surprisingly it ends up in Tallinn. The only "chicks" that intrude as hitchhikers are two "stupid" Soviet girls. Reino drinks heavily like a typical Finn and rocker, but so does Klaudia's alcoholic Russian husband at home. Valto's big black car is, in fact, an old Volga and his car's record player an antiquated Soviet Daisi. Finally, his brand new car's coffeemaker is no more a fetish of modernisation than the Soviet coffee mill he receives from Klaudia as a souvenir. Thus, the Western Finnish "identity" turns out to be nothing but pretence, a rather amusing result of the interplay of cultural signs and imagined differences, which comes into being when faced with its Eastern Soviet Other.

Tatiana's scarf is also a sign of care, empathy, and an intimate identification with the marginal, humble, ex-centric, but utterly humane, Other. Similarly, Kaurismäki's provincial character Taisto Kasurinen (Turo Pajala) in the earlier film Ariel, wears a scarf on his head while, after being left alone, unemployed, and without any prospects for the future, as he drives his father's Cadillac convertible through the Finnish winter. Another "scarfed" character is M (Markku Peltola) in The Man Without a Past (Mies vailla menneisyyttä, Finland, 2002), probably Kaurismäki's most famous film, who after being beaten to death awakes from a coma totally covered in a cast, and later still wears a bandage on his head. Nevertheless, the practical need to protect the protagonists' heads from the cold or from injuries seems to be secondary to the need for the protection and preservation of humaneness, which Kaurismäki's films advocate.

\section{THE SCAR. ANTITHESIS: NEGATIVE OTHER + AUTHENTICITY}

I have already pointed out how the conventional negative image of the Soviet girl is undermined in Kaurismäki's film, i.e. by exploiting her unattractiveness, backwardness, and "stupidity", or what could be conceived as stigmas and scars, to the extent of authentic sincerity and kindness. Tatiana's phony politeness is proven to be genuine by her gentile and altruistic action in the hotel room where she covers the sleeping Reino with the entire blanket, while she has nothing to wrap herself in as she lays at the edge of the bed. A similar discrepancy between empty phrases and devoted deeds is presented in the café scene at the end of their journey when the girls treat their Finnish drivers to tea and Tatiana explains their gesture as a form of gratitude that "will cement the friendship between our nations".

However, Moodysson has a completely different way of representing and subverting stereotypes. This is probably true because his film reproduces the reality of a post-Soviet country a decade after the transition while Kaurismäki's ironic approach "revisits" the past. In a way, Moodysson's film begins where Kaurismäki's ends, i.e. at the Easterner's home. In Kaurismäki's film, Reino decides to stay in Tallinn with Tatiana and we see him last entering her home; while the first scene of Lilya's narrative opens inside Lilya's home with the girl packing her belongings in order to fly away. Moodysson's depiction of Eastern reality that was once imagined to be the promised land of communality is extremely disillusioning and disenchanting. (Figure 4)

Deserted blocks of flats and demolished factories alternate with images of old beggars, abandoned children, and stray dogs. The spirit of egoistic survival commands the behaviour of all who remain there only because they cannot escape. The young Lilya is exposed to a series of betrayals, starting with her mother who flees to 
America and leaves her behind; her aunt who takes Lilya's flat; her best friend who spreads rumours about her; the school teacher and the social worker who just don't care; and finally the false prince charming who cheaply gains her heart and sells her body into slavery in Sweden.

Some critics argue that Moodysson's film indulges in an abusive and obscene view of the Eastern Other (Pavičić 2011). They claim that films such as Lilya 4-Ever (and Take Care of Your Scarf, Tatiana among others) "represent the East in an almost pornographic negativity, emphasizing through a caricature the decay, the injustice, the misery, the social segregation and disorientation of the post-communist society and its individuals. In a strong patronizing manner, these films", according to the same critic, "depict the Easterners as confused children who have unclear and immature notions about the Western world and the reality behind the Iron Curtain." (Pavičić 2011: 86) Pulling at the string of victimisation, Moodysson's film arrives at a stigmatised perception of the Other as a helpless and submissive body that gets used to debasement. The Western gaze peeping from behind the camera sees Lilya's life in a consequential spiral of collapse with rare occasions of escapist revolt or meagre resistance. Thus, Lilya's coming of age story becomes comparable to that of many young Easterners who grew up in the postcommunist transition period. Just as her scar does not heal between the first and the last shot, so too the pessimistic view of her destiny as a victim hardens into judgment.

\section{(Figure 5)}

On the other hand, the story in Lilya 4-Ever is meant to play homage to the stories of all the victims of the sex trade, and in this sense, as Moodysson pointed out in an interview, the cultural realities of Russia and Sweden fade out altogether, and instead become a parable about "the gap between the rich and the poor", an allegory of contemporary worldly ills (Michael 2003). Moodysson is known for his cinematic mastery in filming uneasy coming-of-age stories (Show Me Love/Fucking Àmål,
Sweden/Denmark, 1998; We Are the Best!/Vi är bäst!, Sweden/Denmark, 2013) as well as for pouring salt on social wounds (Terrorists: The Kids They Sentenced/Terrorister - en film om dom dömda, Sweden, 2003; A Hole in My Heart/Ett hål i mitt hjärta, Sweden/ Denmark, 2004; Container, Sweden, 2006; Mammoth, Sweden/Denmark/Germany, 2009). With Lilya 4-Ever, he reached a point of critical engagement that goes beyond the mere representation of geopolitical Selves and Others - as an auteur, he clearly takes the side of the outcast enfants terrible who easily become victims of the worldly order. And that is why the film's representation of wealthy Sweden - the concrete deserts of Malmö, the daily McDonalds' meal given to a sex-slave, the perverted male customers, the shops brimming with goods but lacking goodness - looks like a prison even worse than Lilya's post-communist open-air hell.

The strong drive towards the documentary and authentic in Moodysson's film matches its brutal realism, but it also projects its powerful colours on the depiction of Lilya's moral beauty, for instance, in her maternal-like care for her young friend Volodya (Artyom Bogucharski). In another interview, Moodysson acknowledges that the character of Volodya was a subconscious product of the director's initial intention to create an invisible Christ who would accompany Lilya on her path of suffering (Leigh 2002). Indeed, alongside the scenes of deliberate naturalism, the film creates a parallel religious or transcendental dimension - in which outcast Lilya and Volodya are quite literally represented as innocent angels wearing large white wings. Therefore, the blatantly negative representation of the post-Soviet and Western capitalist realities are alleviated and contrasted through the true friendship and genuine compassion that exists between the two kids.

There are two almost identical scenes of cinematic ingenuity in Lilya and Tatiana that visualise pure intimacy without sugarcoated sentimentality. These are the moment in the early morning when Reino sits down next to Tatiana, she rests her head on his shoulder and he embraces her; and 


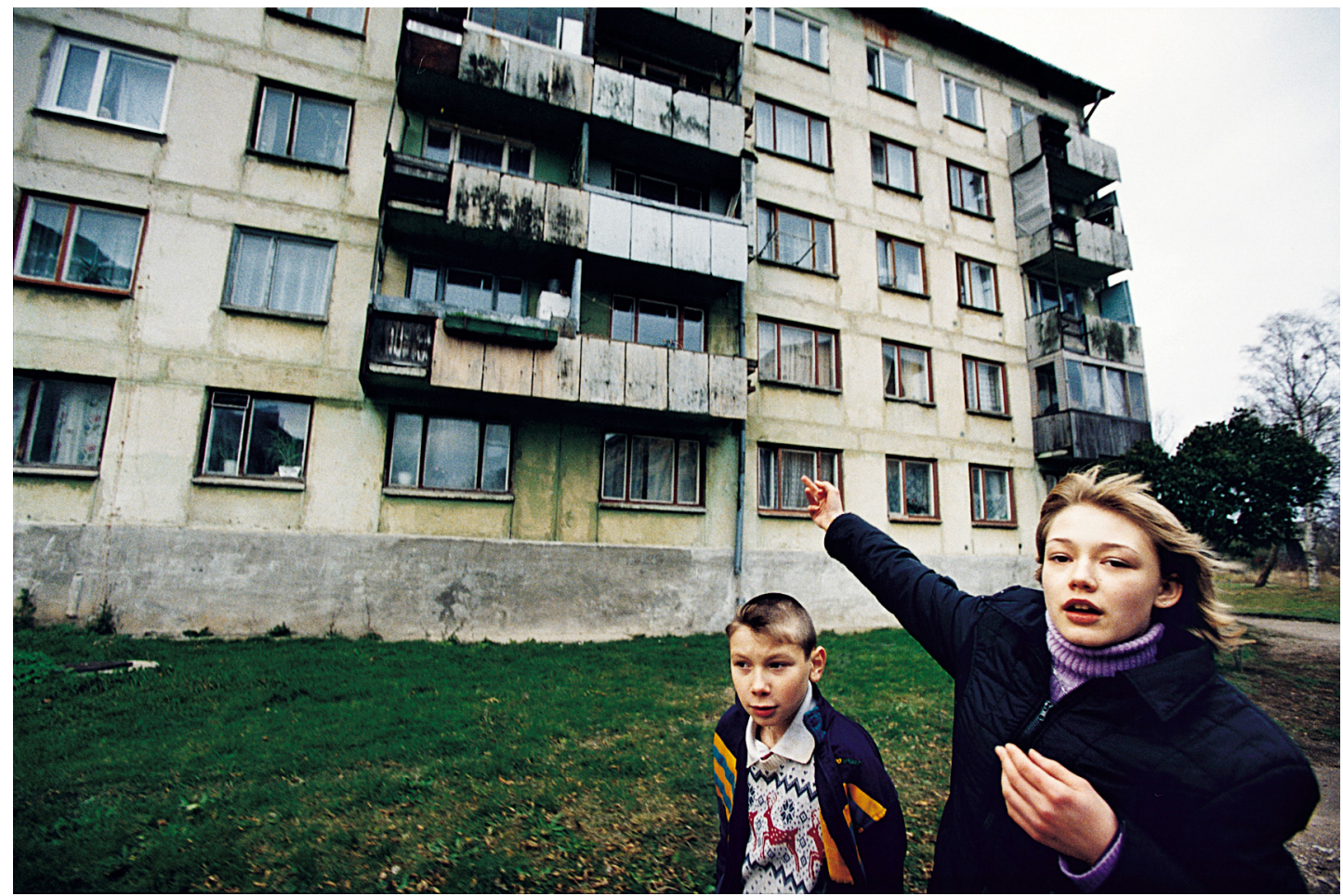

FIGURE 4. CMemfis Film/Per-Anders Jörgensen.

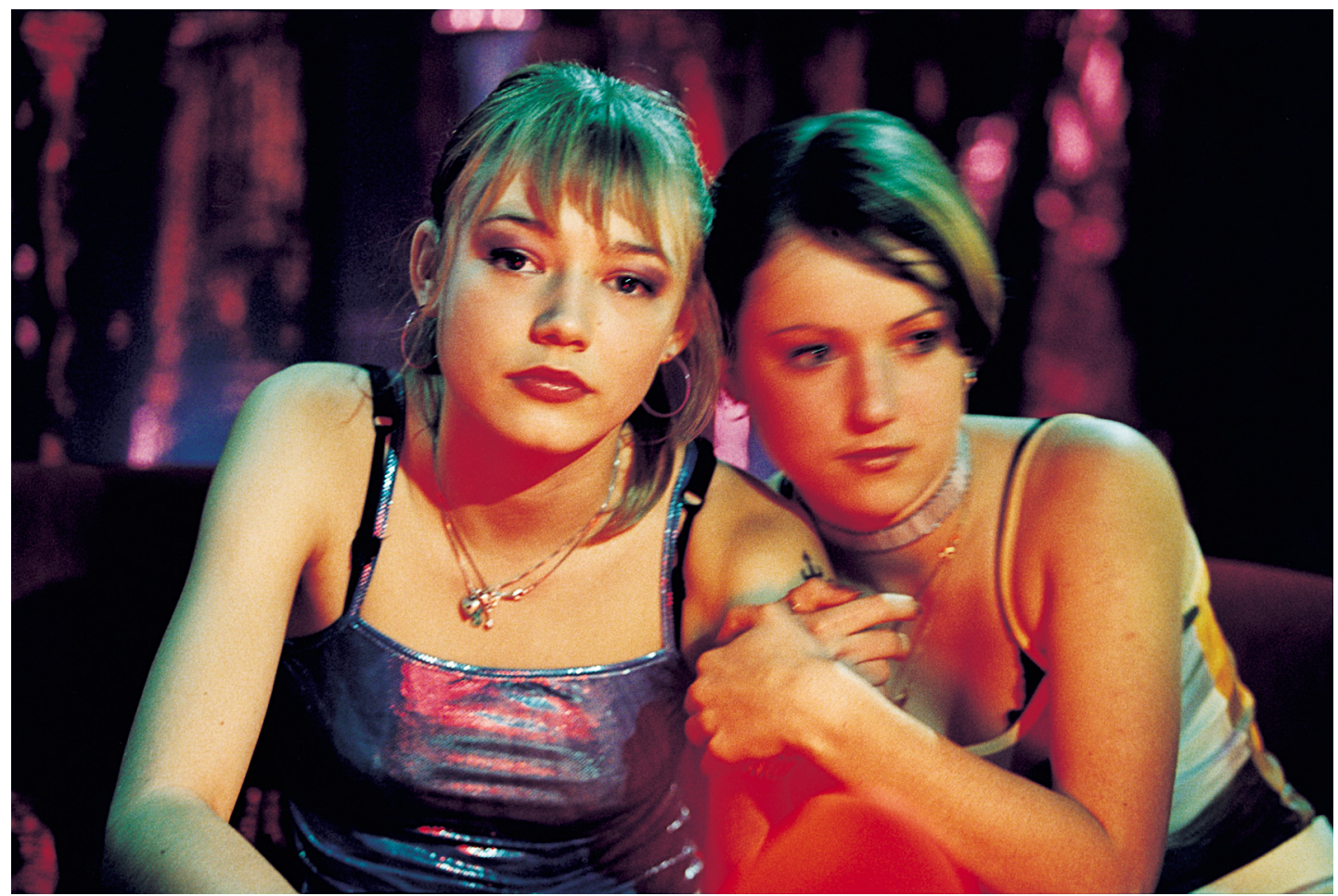

FIGURE 5. CMemfis Film/Per-Anders Jörgensen. 
the after-party scene in which Volodya looks kindly at weeping Lilya and rests his head on her shoulder in order to console her as well as himself. The scene in Tatiana is cooler in feeling than the one in Lilya, partly because it is filmed in black-and-white and partly because of the ironic tone that dominates Kaurismäki's film. Actually it is another example of an image from Dreyer's Gertrud (Denmark, 1964) that Kaurismäki first borrowed for his film Hamlet Goes Business (Hamlet liikemaailmassa, Finland, 1987), in which two people who are in love sit on a sofa looking straight ahead and not at each other, which Kaurismäki considers the epitome of depicting the unsentimental ideal of passion (Toiviainen 2004: 24). (Figure 6)

The musical score in Moodysson's film serves as another antithetical commentary on Lilya's stigmatised image as a prostituting body. The film's intro, which later becomes the film's closure, is scored with the heavy sensibility of Rammstein's Mein herz brennt (My Heart Burns), which conveys the film's fervent appeal to compassion and redemption. The fragments of Sinfonia in B minor Al Santo Sepolcro by Antonio Vivaldi, which can be heard in the scenes of Lilya's isolation, are also calling for justice and salvation. They are contrasted with motifs from Russian techno and disco songs, illustrating the ingenuousness and naïveté of the girl's soul. Thus, the film's visual and audible components gradually portray an unstained spiritual image of a child that gets lost in our deceitful world. Moodysson's Lilya becomes an image equally distanced from the stigmas of the weak Easterner as of the abused female; she acquires a sacred aura of the "meek", the "poor in spirit", and the "pure in heart", or someone who will be blessed, who "shall see God" and be in "the kingdom of heaven".

Evidently, both Nordic films try to see the Other through scars - through the clichés and the stigmas that characterise the popular image of Her. Their ethical and aesthetical commitment can be defined as empathic and redemptive.

\section{THE SCAR(F). SYNTHESIS: POSITIVE OTHER + AUTHENTICITY}

Unlike the couple in Carl Dreyer's blackand-white and sarcastic film They Caught the Ferry, who reached the ferry only after they are killed in a motorbike accident, Kaurismäki's protagonists reach the ferry in time and alive, and even infatuated with each other. The low-contrasting pictures on the ship deck are probably the best illustration of the sentimental attraction and ironic blending of the cultural differences between the Finnish Self and the Eastern Other that Kaurismäki expresses through his film. Significantly, the scenes' romantic location on the open ship deck, in the middle of the Baltic Sea, serves to emphasise their idyllic, trance-national and dreamlike character. These images reflect another cliché about true love that overcomes all borders by showing how Tatiana's scarf becomes undone by the wind and the Reino's otherwise shy and fleeting gaze finally fixates on her. The pathetic Finnish waltz that is heard during these scenes - another example of the intrusion of late 1950s schlagers into the modern rock 'n' roll tunes - turns it all into a reverie contemplated with mild irony.

However, the ferry sequence is only an omen of the final ironic coda of the film, in which the positive and the genuine meet in a sort of fantasy. The film's message seems to be presented by the wishful daydream of Valto, who is left alone at the end of the journey and thrown back into Finnish reality. On his way home, he imagines that everybody is in his car again and he drives it directly into a café, crashing in through the window. Without getting out of the black Volga that is now standing in the middle of the smashed café, Valto orders coffee from the barman and everybody listens to rock 'n' roll again. True to the film's ethos, desire finally destroys the stigmatising social reality and moves the opposites - the Self and the Other -closer to each other in a state of delight. Valto's daydream is a metonymy of the consistent, but also consciously selfironic and humane pathos of Kaurismäki's 
BALTIC SCREEN MEDIA REVIEW 2014 / VOLUME 2 / ARTICLE

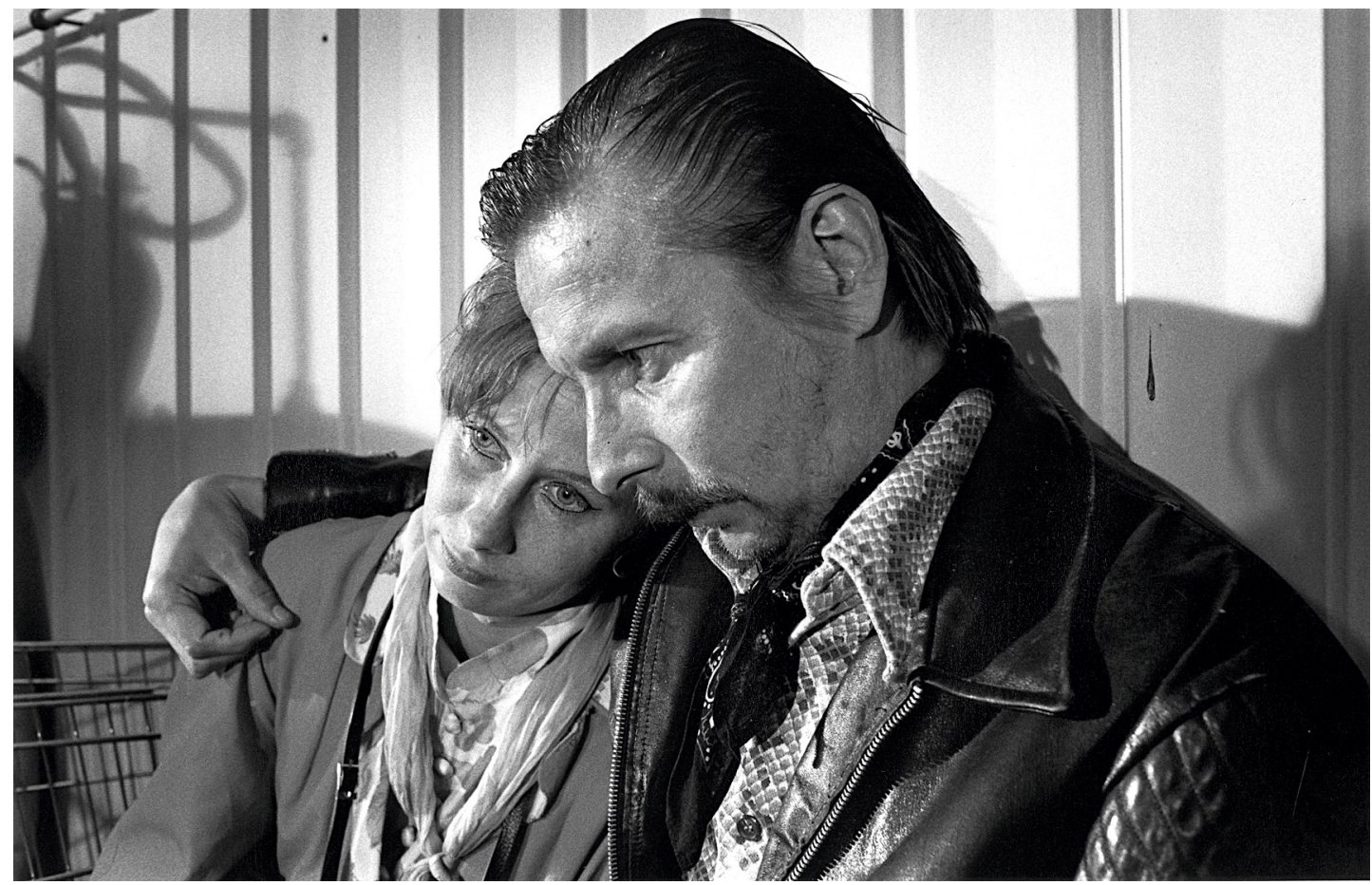

FIGURE 6. CSputnik OY. 
cinema, of its Sisyphean effort to repair the damage, heal the wounds, and help those in trouble, at least in the illusionary world of cinematic reality.

Similarly, the catharsis in Moodysson's tragic narrative is conceived as the fulfilment of a last wish. Shortly before her death, Lilya sees herself back home playing basketball with Volodya, helping the wicked old neighbour and refusing to be fooled by her deceitful boyfriend. Death comes as a reunion of two angels: Lilya and Volodya are wearing large white wings; they are prancing and are now "4-ever" happy and free. Also, this liberating image is located on a rooftop, and for the first time, the camera provides a panoramic perspective that reveals, although only partly and shortly before the end, the depressing exteriors of endless blocks of flats. In the last sequence, we see the Baltic Sea - grey and barely a rim, but still marking the horizon with its borderlessness. This spiritual counterpoint to the otherwise over-naturalistically depicted reality in the film is scant consolation. Nevertheless, it is an epilogue suited to tragedy, and encourages the viewer to identify with the suffering of Lilya to find a positive release.

In conclusion, one could say that the comparison of the negative and positive elements that organise the representations of Eastern European in the two Nordic films reveals temporary and historically contingent images of a feminised Other, whose cinematic appearance depends greatly on the directors' artistic challenging of popular collective prejudices. It has been noted that the negative components in the images of Tatiana and Lilya do not pertain to the characters' individual psychology, but are primarily the evaluations of historical and societal contexts. That is, making Kaurismäki's heroine into an outmoded and rigid fool comprised of clichés serves as an implicit commentary on the backward and rigid Soviet system. Similarly, Lilya's stigmatisation as a prostitute, or, in the gentler melodramatic conception of Moodysson's film as a naïve and unruly girl that becomes easy prey for worldly evil, refers more to the postSoviet state of social chaos and degrada- tion. Therefore, both films retransmit and then challenge two different, historically conditioned popular conceptions of Eastern Europe before and after the fall of the Berlin Wall. Thus, the cliché and the stigma (the scarf and the scar) have been used in the films deliberately to signify the collective Western attitudes towards concrete Eastern European socio-cultural contexts.

However, one of the goals of these two films has been to undermine the popular reductive images about Eastern Europe and the ease with which they form public opinion. One could say that in their very different approaches, Kaurismäki and Moodysson succeed in projecting a positive image of the Eastern European Other beyond the scarf and the scar. This has been achieved, but not only, thanks to the individual charisma and good performance of the leading parts: Kati Outinen (Tatiana), who is famous in Finland and abroad and has played the noble female protagonist in most of Kaurismäki's films, and the young and talented Oksana Akinshina (Lilya) who performed her difficult role with dignified endurance. Another reason why the stories of Lilya and Tatiana overcame the stereotyping might be because both directors chose melodrama as the cinematic genre that is traditionally the best advocate for "fallen" female characters. Obviously, Kaurismäki's Tatiana is an unconventional and overtly un-dramatic melodrama that turns out to be mostly an ironic inquiry into the national Finnish character. Lukas Moodysson chose the classical strategy of tragic melodrama that eventually channels the western audience's feelings of pity and outrage into genuine compassion and transforms the story of Lilya into a Christian parable. Therefore, both films initially establish and then contest the collective stereotypes about the feminised Eastern European Other, subsequently turning their scrutiny inwardly towards the perception of their own identity and Western morality. 


\section{REFERENCES}

Bakić-Hayden, Milica 1995. 'Nesting Orientalisms: The Case of Former Yugoslavia'. - Slavic Review, 54, 4, 917-931.

de Beauvoir, Simone [1949] 1989. The Second Sex.

Trans. and ed. H. M. Parshley. New York: Vintage Books. Elonet Kansallisfilmografia 2013. http://www.elonet.fi/ fi/elokuva/147864\#undefined (10 December 2013). Hegel, Georg Wilhelm Friedrich [1807] 1977.

Phenomenology of Spirit. Trans. A. V. Miller. Oxford: Oxford University Press.

Kaurismäki, Aki; Hukkanen, Marja-Leena 1997.

Schatten im Paradies - von Leningrad Cowboys bis Wolken ziehen vorüber. Die Filme von Aki Kaurismäki. Trans. Jürgen Warmbrunn. Berlin: Schwarzkopf \& Schwarzkopf.

Leigh, Danny 2002. 'Lukas Moodysson at the NFT'. The Guardian, 20 November.

http://www.theguardian.com/film/2002/nov/20/ features.dannyleigh (20 August 2014).

Michael, David 2003. 'Interview with Lukas Moodysson'. - BBC Movies, 28 March.

http://www.bbc.co.uk/films/2003/03/28/lukas_ moodysson_lilya_4_ever_interview.shtml (20 August 2014).

Nestingen, Andrew 2005. 'Aki Kaurismäki's Crossroads: National Cinema and the Road Movie.' - Andrew Nestingten, Trevor G. Elkington (eds.), Transnational Cinema in a Global North: Nordic Cinema in Transition.

Detroit: Wayne State University, 279-305.

Pavičić, Jurica 2011. Postjugoslavenski film, stil i ideologija. Zagreb: Hrvatski filmski savez.

Romney, Jonathan 2003. 'Last Exit to Helsinki'. Film Comment, 39, 2, 43-45, 47.

Said, Edward [1978] 2003. Orientalism. London: Penguin Books.

Todorova, Maria 1997. Imagining the Balkans. Oxford, New York: Oxford University Press.

Toiviainen, Sakari 2004. 'The Kaurismäki Phenomenon: - Journal of Finnish Studies, 8, 2, 20-45.

Wolff, Larry 1994. Inventing Eastern Europe: The Map of Civilization on the Mind of the Enlightenment. Stanford: Stanford University Press. 